\title{
Determination of the Compatibility Between \\ Structural Alloys and Molten Metals \\ at High Temperatures
}
G. A. Henshall
L. M. Wagner
B. A. Westfall
R. P. Kershaw

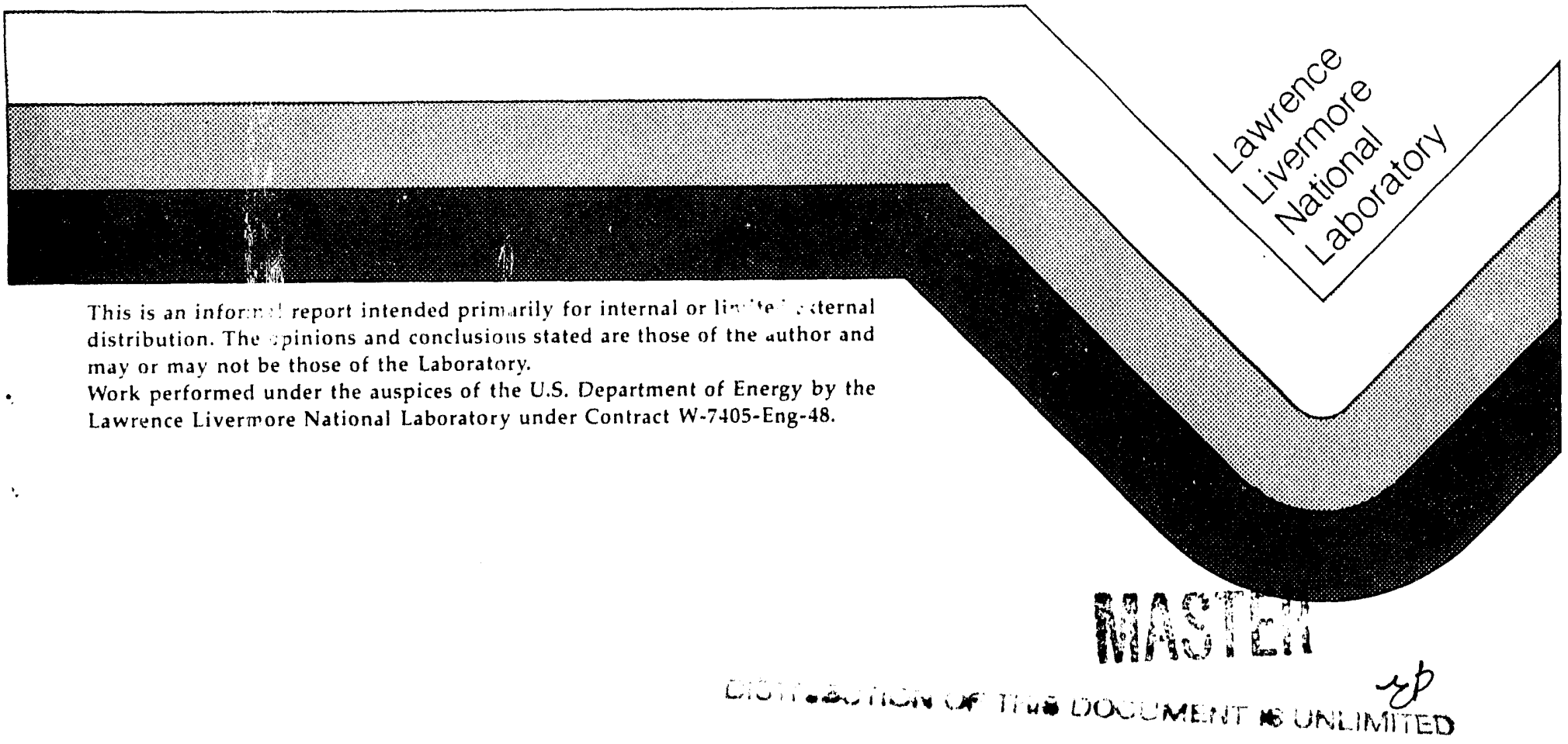




\section{DISCLAIMER}

This document was prepared as an account of work sponsored by an agency of the United States Government. Neither the United States Government nor the University of California nor any of their employees, makes any warranty, express or implied, or assumes any legal liability or responsibility for the accuracy, completeness, or usefulness of any information, apparatus, product, or process disclosed, or represents that its use would not infringe privately owned rights. Reference herein to any specific commercial products, process, or service by trade name, trademark, manufacturer, or otherwise, does not necessarily constitute or imply its endorsement, recommendation, or favoring by the United States Government or the University of California. The views and opinions of authors expressed herein do not necessarily state or reflect those of the United States Government or the University of California, and shall not be used for advertising or product endorsement purposes.

This report has been reproduced directly from the best available copy.

A vailable to DOE and DOE contractors from the Office of Scientific and Technical Information

P.O. Box 62, Oak Ridge, TN 37831

Prices a vailable from (615) 576.8401, FTS 626.8401

Available to the public from the

National Technical Information Service

US. Department of Commerce 5285 Port Royal Rd.

Springfield, VA 22161 


\title{
Determination of the Compatibility Between Structural Alloys and Molten Metals at High Temperatures
}

\author{
G. A. Henshall, L. M. Wagner, B. A. Westfall and R. P. Kershaw
}

\begin{abstract}
The experimental methods for determining the high temperature compatibility between structural alloys and molten metals, particularly braze alloys, have been established. The structural alloys of interest are formed or machined into small crucibles into which the metal to be melted is placed. This system is placed in a furnace which typically will have a vacuum or inert gas environment; other atmospheres are possible as well. Multiple crucibles are exposed for various times and temperatures. Following cooling, a visual examination for loss of containment is performed. Each crucible is then sectioned and examined metallographically to document any loss in thickness of the crucible or any reactions between the materials. These procedures are fairly simple and require only common laboratory equipment; costs, therefore, are kept low.

These experimental techniques were refined for use in deternining the compatibility of both commercially pure vanadium and 21-6-9 stainless steel with a $92.5 \% \mathrm{~Pb}-5 \% \mathrm{In}-2.5 \% \mathrm{Ag}$ braze alloy. Both the vanadium and the stainless steel contained the molten $\mathrm{Pb}$-In- $\mathrm{Ag}$ alloy for exposures ranging from $1000^{\circ} \mathrm{C}$ for 10 minutes up to $1200^{\circ} \mathrm{C}$ for 2 hours.
\end{abstract}




\section{Introduction}

The safety of nuclear weapons in an accidental hydrocarbon fuel fire is a problem of great interest at Lawrence Livermore National Laboratory (LLNL). During such an event, some components may be exposed to temperatures of approximately $1200^{\circ} \mathrm{C}$ for up to two hours [1]. The compatibility of various materials under these extreme conditions must be ensured to certify that radioactive and toxic materials are not released into the environment during such an accident. Of concern in the present study is the case in which one material, typically a braze alloy ${ }^{\dagger}$, is molten at the high temperature while another remains below its melting point.

While phase diagrams give some information relating to material compatibility at high temperatures, this information is incomplete. First, phase diagrams do not give any kinetic information, which may be relevant for the exposures of interest in this investigation. More importantly, complete phase diagrams typically are unavailable for complex alloys, such as those most often used in weapons systems. This is especially true for the case in which the molten material is not a pure metal. Therefore, experimental methods must be used to determine material compatibility in most cases.

This report describes the experimental methods that have been developed to determine the degree of compatibility between sets of materials at high temperatures, as well as the results of experiments performed to date. The report is divided into two major sections. The first describes the general experimental method. This section is written in as general a way as possible, with only a few underlying assumptions regarding the nature of the materials to be tested (e.g. one material is molten while the other remains solid). The second major section describes in detail the experiments performed to date using this general method. Specifics regarding the method are included along with the

$\dagger$ Throughout this report, the low melting temperature alloy is assumed to be a braze alloy, though this is not a necessary condition for the successful application of the test methods described. 
results for both commercially pure vanadium and 21-6-9 stainless steel in contact with a 92.5\% $\mathrm{Pb}-5 \% \mathrm{In}-2.5 \% \mathrm{Ag}$ braze alloy. Finally, the conclusions from this work are presented.

\section{General Experimental Method}

\section{Qverview}

The test method employed is conceptually quite simple. The alloy expected to remain solid at the test temperature, or "high temperature alloy", is formed into a small crucible into which a small amount of the braze alloy is placed. This system is placed into a furnace and held at the test temperature, at which the braze alloy is molten. Figure 1 presents a sketch of the basic experimental set-up. If the high temperature alloy is oxidation resistant or information is required for the case in which air is present, the furnace atmosphere could be air. In this report, however, it is assumed that an inert environment is of interest, so a vacuum or inert gas is used. The test temperature is held for the desired length of time and then the system is cooled quickly to room temperature. The crucible is removed and visually examined to see if the molten metal reacted with the

? high temperature alloy to the extent that it pierced the crucible. This, of course, would constitute failure. If no such obvious failure occurred, the crucible containing the solidified braze pool is then sectioned and examined using suitable optical methods to determine the extent of the reaction between the alloys. Depending on the actual geometry in the system of interest (e.g. section thickness) the degree of reaction may be either acceptable or unacceptable. This process is repeated with separate crucibles for any desired set of exposure conditions.

While this test method is fairly simple, which keeps costs low, a number of experimental details need to be carefully addressed to assure its success. The remainder of this section and portions of the next section document some of these details. 


\section{Materiais}

The braze alloy will be molten at the temperatures of interest, so it may be in any suitable form with any microstructure. Only the alloy composition must be carefully chosen to match that of the material of interest. For the high temperature alloy, somewhat more care must be taken. Microstructurally, the phases that are present in the actual material should be present in the material used for the test. If grain boundary attack is suspected to be a problem, then the grain size may be important (although rapid grain growth is likcly at temperatures as high as $1200^{\circ} \mathrm{C}$ ). Otherwise, microstructure is not expected to play a large role in the outcome of the tests. Cold work, for example is not expected to be important for most materials since it will be annealed out at the test temperature.

Fabrication steps for forming the crucible from the high temperature alloy depend on the form of the stock material, as well as the properties of the material itself. For most materials, crucibles can be easily formed from sheet using a dimpling procedure, such as that described in Section III. Rolling or other procedures could be used to produce sheet if the stock material has another form. Machining methods also could be used to fabricate crucibles so long as they do not contaminate or otherwise alter the surface of the material. The goal is simply to provide a container for the liquid metal that is representative of the structural alloy component. As described in Section III, evaporation of the molten braze alloy may require that the crucible include a lid made from the high temperature alloy. One method of providing for this need is described in Section III. Finally, there is no specific thickness to which the crucible must be manufactured. Based on experience, a thickness of at least $0.5 \mathrm{~mm}$ is recommended. The exact thickness will depend on the expected degree of attack and on the amount of the braze alloy being used, with the crucible thickness increasing as the amount of braze alloy increases. Small specimens (e.g. of the dimensions given in Section III) should be adequate and are recommended. 


\section{Eurnace and Environment}

Figure 1 shows the general configuration of the crucible and low temperature braze alloy within the furnace. The crucible is placed within a container made from a very high temperature inert material, such as $\mathrm{Mo}, \mathrm{Ta}$ or $\mathrm{Al}_{2} \mathrm{O}_{3}$, in case containment of the molten braze alloy is lost. At least one thermocouple should be in contact with the crucible to accurately measure temperature.

Evaporation of the braze alloy during exposure must be considered. Extensive vaporization of the braze alloy may cause loss of most or all of the liquid, and also may result in destruction of the thermocouples due to reactions with the vapor. Therefore, if the crucible is uncovered, the furnace needs to be back-filled with an inert gas to reduce evaporation of the molten metal. The higher the back pressure, the higher the temperature that can be reached without losing a significant amount of the braze alloy. If a high enough back pressure cannot be achieved or if vacuum conditions are desired, then the crucible must be covered. A method for achieving this is described in Section III.

\section{Testing}

Testing is fairly straightforward. First, a matrix of times and temperatures is selected, and one crucible/braze alloy system is tested for each set of exposure conditions. Beginning with relatively low temperatures and short times is recommended to gain confidence in the capability of the high temperature alloy to provide containment for the molten metal. It is also desirable to have a permanent log of the temperature-time history of each crucible to be cer:ain that no temperature spikes have occurred. Such spikes could occur due to experimental error or because of exothermic reactions taking place between the materials. Following exposure, cool down should take place as rapidly as possible, though extreme measures are not needed to produce extremely high cooling rates; quenching, for example, is not needed. Following each test, the crucible should be examined visually for breach of containment. 


\section{Metallography}

After the visual examination, each crucible, which now contains a solidified pool of the braze alloy, should be cross sectioned for metallographic examination. The techniques used to prepare the metallographic specimens will depend upon the materials being tested. Care generally will be required since the hardness and chemical properties of the two materials are likely to be quite different.

Examination of the cross sections should be done first at a magnification low enough to measure the thickness of the high temperature alloy crucible, both under the solidified braze pool and far from the pool. In this way, any loss in thickness of the crucible due to reaction at high temperature with the braze metal can be measured. Several micrographs may be required to document any spatial variation in dissolution. Next, higher magnification examinations may be needed to document any reaction products at the interface or grain boundary attack. If necessary, microprobe traces could be used to track the diffusion of elements across the interface. In most cases, however, this level of detail will not be warranted since the primary concern is simple: the high temperature alloy either provides containment for the molten metal or it is breached.

\section{Compatibility of Commercially Pure Vanadium and 21-6-9 Stainless Steel with a 92.5\% Pb-5\% In-2.5\% Ag Braze Alloy}

This section provides a detailed description of the experimental procedures used and the results obtained in the determination of the high temperature compatibility of commercially pure vanadium and 21-6-9 stainless steel with a $92.5 \% \mathrm{~Pb}-5 \% \mathrm{In}-2.5 \% \mathrm{Ag}$ braze alloy. Exposures varied from $1000^{\circ} \mathrm{C}$ for 10 minutes up to $1200^{\circ} \mathrm{C}$ for two hours. 


\section{Materials}

The high temperature alloys tested included commercially pure vanadium, with the composition given in Table 1, and Weapons Grade 21-6-9 stainless steel, with the composition given in Table 2. The vanadium stock was in the form of $1 / 8$-inch thick plate. This plate was rolled without intermediate anneals to a thickness of 0.018 to 0.019 inches. The stainless steel was received as 1/4-inch thick plate. This plate was cold rolled, annealed at $1000^{\circ} \mathrm{C}$ for 15 minutes and then cold rolled to a thickness of 0.018 to 0.019 inches. Crucibles of each material were formed simply by pressing the sheet over a ball bearing using a vice. The crucible dimensions are given in Fig. 2(a). Prior to emplacement of the braze alloy, the surface of each crucible was cleaned by wiping and rinsing with acetone.

The $92.5 \% \mathrm{~Pb}-5 \% \mathrm{In}-2.5 \% \mathrm{Ag}$ braze alloy $\left(\mathrm{T}_{\mathrm{m}}=310^{\circ} \mathrm{C}\right)$ was received in the form of 0.002 -inch thick foil. A one-inch square piece of this foil (approx. 4 grams) was used for each test. For the $1200^{\circ} \mathrm{C} / 2$-hour test, it was necessary to encapsulate the braze alloy to avoid evaporation. This was performed by placing the braze foil in one crucible and placing another crucible over the top of the first, as shown in Fig. 2(b). This assembly was placed in vacuum and electron beam welded shut.

\section{Eurnace and Environment}

The test matrix of exposure times and temperatures is given in Table 3, and was selected to probe the high temperature compatibility of the materials while minimizing the potential problems of the molten $\mathrm{Pb}-\mathrm{In}-\mathrm{Ag}$ alloy breaching containment and fouling the vacuum furnace. Thus, an exposure of $1000^{\circ} \mathrm{C}$ for only 10 minutes was chosen as a starting point for the experiments. The temperature and exposure time then were increased systematically until the most severe exposure of interest was reached: $1200^{\circ} \mathrm{C}$ for 2 hours. As experience was gained, some changes were made to the furnace and 
environment to provide for the high temperatures and to avoid evaporation of the $\mathrm{Pb}$-InAg alloy.

Two different types of furnaces were used during this investigation. For the 10-, 30-, and 60-minute exposures, the furnace geometry shown schematically in Fig. 3(a) was employed. For the 2 -hour exposures, this geometry proved to be inadequate, so the geometry shown in Fig. 3(b) using a water-cooled jacket was employed. For all exposures except the $1200^{\circ} \mathrm{C} / 2$-hour exposure, the furnace was evacuated and then back filled with $1 / 2$ atmosphere of argon. For the $1200^{\circ} \mathrm{C} / 2$-hour tests, the $\mathrm{Pb}-\mathrm{In}$ - $\mathrm{Ag}$ alloy was encapsulated as described earlier, so no argon backfill was required. In all cases, a thermocouple in contact with the crucible was used to measure the temperature of the system.

\section{Testing}

An example of the temperature-time history of the crucible during exposure is given in Fig. 4. Note the rapid rise in temperature, smoothly reaching the desired test temperature (in this case $1000^{\circ} \mathrm{C}$ ), the stable hold period, and the rapid decrease from the hold temperature. All of these aspects of the exposure are desirable for the compatibility tests and are typical of the results we achieved.

Following high temperature exposure, the crucibles were examined visually for a breach of containment. Under no conditions was containment ever lost for either the vanadium or the stainless steel, as indicated in Table 3. In some cases where a cover was not welded onto the top of the crucible, some loss of the braze alloy did occur. These losses increased as the severity (time or temperature) of the exposure increased.

\section{Metallography}

The tested specimens were cross sectioned and prepared metallographically by polishing with alumina and electrolytically etching with oxalic acid. Examination of 
these metallographic specimens revealed the following. For temperatures below $1200{ }^{\circ} \mathrm{C}$ the results of the exposures were all very similar. For example, Fig. 5 shows results for the 60 -minute exposure of vanadium at $1100^{\circ} \mathrm{C}$. Figure $5(\mathrm{a})$ shows a low magnification view of the vanadium crucible and the upper surface of the solidified braze pool. Thickness measurements of the $\mathrm{V}$ just above and just below the solidified pool confirm that the loss in cross section of the $V$ was small. For the case shown in Fig. 5(a), the loss in thickness was $2.45 \%$; this was the maximum loss of all the tested exposures below $1200{ }^{\circ} \mathrm{C}$. Figure 5(b) shows a higher magnification view of the vanadium $/ \mathrm{Pb}-\mathrm{In}-\mathrm{Ag}$ interface. Dendrites of a second phase are visible in the $\mathrm{Pb}-\mathrm{In}-\mathrm{Ag}$ alloy, but the interface is planar and no second phases were produced in the vanadium. Most important, there is no grain boundary or other localized attack in the vanadium. Small voids did appear in the vanadium, however, for this and other exposures. The origin of these voids is not known but may be due to Kirkendall diffusion [2].

For the 2-hour exposures at $1200{ }^{\circ} \mathrm{C}$ there is evidence of some reaction or melting of the high temperature alloy at the interface with the $\mathrm{Pb}-\mathrm{In}-\mathrm{Ag}$ alloy. Figure 6(b) gives an example for 21-6-9 stainless steel. As shown in Fig. 6(a) however, these effects were localized to the interface and there was never any significant loss in thickness of the base metal. Measurements show that the loss in thickness for this exposure was only $2.1 \%$ for vanadium and $2.2 \%$ for stainless steel. Containment of the $\mathrm{Pb}-\mathrm{In}-\mathrm{Ag}$ alloy was never in question for either high temperature alloy. 


\section{IY. Conclusions}

1. A general experimental method has been established and demonstrated for testing the high temperature compatibility between a low-melting alloy and a high-melting one. This test method is applicable to complex engineering materials, and is low cost and simple to apply.

2. This test method was refined and applied successfully to determining the compatibility between a $92.5 \% \mathrm{~Pb}-5 \% \mathrm{In}-2.5 \% \mathrm{Ag}$ braze alloy and both commercially pure vanadium and 21-6-9 stainless steel.

3. Results of these tests show that both vanadium and 21-6-9 stainless steel contain the $92.5 \% \mathrm{~Pb}-5 \% \mathrm{In}-2.5 \% \mathrm{Ag}$ alloy at temperatures up to $1200{ }^{\circ} \mathrm{C}$ for exposures of up to 2 hours. The maximum loss in thickness of the vanadium or stainless steel was only about $2.45 \%$ or $11 \mu \mathrm{m}$.

\section{Acknowledginents}

The authors wish to thank Dr. James Hanafee for his guidance and support throughout this study, and for his helpful comments on the manuscript.

\section{References}

1. J. A. Mansfield, J. M. Technical, and L. J. Linley, "Measurement and Statistical Analysis of Flame Temperatures from Large Fuel Spill Fires," Naval Weapons Center report no. NWCTP7061, January 1991.

2. P. G. Shewmon, Diffusion in Solids, McGraw-Hill, New York (1963). 


\section{List of Figures}

1. Schematic illustration of the general experimental arrangement for testing the compatibility of materials at high temperatures.

2. Geometry of the vanadium and 21-6-9 stainless steel crucibles for exposures (a) less than 2 hours at $1200^{\circ} \mathrm{C}$, and (b) $1200^{\circ} \mathrm{C}$ for 2 hours.

3. Furnace configurations for exposures (a) less than 2 hours and (b) 2 hours.

4. The temperature vs. time history for a 10 -minute exposure at $1000^{\circ} \mathrm{C}$.

5(a). Micrograph showing the result of an $1100^{\circ} \mathrm{C} 60$-minute exposure of commercially pure vanadium to the $\mathrm{Pb}-\mathrm{In}-\mathrm{Ag}$ braze alloy. (a) Low magnification view of a cross section of the crucible and solidified pool.

5(b). Micrograph showing the result of an $1100{ }^{\circ} \mathrm{C} 60$-minute exposure of commercially pure vanadium to the $\mathrm{Pb}-\mathrm{In}-\mathrm{Ag}$ braze alloy. (b) High magnification view of the interface between the alloys.

6(a). Micrograph showing the result of a $1200{ }^{\circ} \mathrm{C}$ 2-hour exposure of 21-6-9 stainless steel to the Pb-In-Ag braze alloy. (a) Low magnification view of a cross-section of the crucible and solidified pool.

$6(\mathrm{~b})$. Micrograph showing the result of a $1200^{\circ} \mathrm{C} 2$-hour exposure of 21-6-9 stainless steel to the $\mathrm{Pb}-\mathrm{In}-\mathrm{Ag}$ braze alloy. (b) High magnification view of the interface between the alloys. 
Table 1. Nominal Chemical Composition of Commercially Pure Vanadium.

\begin{tabular}{|c|c|}
\hline Element & Content (Wt. \%) \\
\hline $\mathrm{V}$ & Balance $(\approx 99.8)$ \\
\hline $\mathrm{H}$ & $<0.0005$ \\
\hline $\mathrm{O}$ & 0.030 \\
\hline $\mathrm{N}$ & 0.0055 \\
\hline $\mathrm{C}$ & 0.003 \\
\hline $\mathrm{Al}$ & 0.025 \\
\hline $\mathrm{Si}$ & 0.035 \\
\hline $\mathrm{Fe}+\mathrm{Ni}+\mathrm{Cr}$ & 0.014 \\
\hline $\mathrm{Ti}+\mathrm{Zr}+\mathrm{Hf}$ & $<0.025$ \\
\hline $\mathrm{Nb}+\mathrm{Mo}+\mathrm{Ta}$ & 0.070 \\
\hline $\mathrm{P}+\mathrm{S}$ & 0.004 \\
\hline
\end{tabular}


Table 2. Nominal Chemical Composition of 21-6-9 Stainless Steel.

\begin{tabular}{|c|c|}
\hline Element & Content (Wt. \%) \\
\hline $\mathrm{Fe}$ & Bal. \\
\hline $\mathrm{Cr}$ & 19.5 \\
\hline $\mathrm{Ni}$ & 6.5 \\
\hline $\mathrm{Mn}$ & 9.4 \\
\hline $\mathrm{Si}$ & 0.50 \\
\hline $\mathrm{P}$ & 0.011 \\
\hline $\mathrm{S}$ & 0.010 \\
\hline $\mathrm{Al}$ & 0.015 \\
\hline $\mathrm{O}$ & 0.002 \\
\hline $\mathrm{N}$ & 0.30 \\
\hline $\mathrm{C}$ & 0.025 \\
\hline
\end{tabular}


Table 3. Test Matrix for the $\mathrm{Pb}-\mathrm{In}-\mathrm{Ag}$ Alloy Containment.

\begin{tabular}{|c|c|c|c|}
\hline Material & Temperature $\left({ }^{\circ} \mathrm{C}\right)$ & Time (min.) & Result \\
\hline Vanadium & 1000 & 10 & Contained \\
\hline$"$ & 1000 & 30 & $"$ \\
\hline$"$ & 1000 & 120 & $"$ \\
\hline$"$ & 1100 & 10 & $"$ \\
\hline$"$ & 1100 & 60 & $"$ \\
\hline$"$ & 1200 & 10 & $"$ \\
\hline$"$ & 1200 & 120 & Contained \\
\hline $21-6-9$ SS & 1000 & 10 & $"$ \\
\hline$"$ & 1000 & 30 & $"$ \\
\hline$"$ & 1000 & 120 & $" 10$ \\
\hline$"$ & 1100 & 120 & $"$ \\
\hline$"$ & 1200 & & $"$ \\
\hline
\end{tabular}




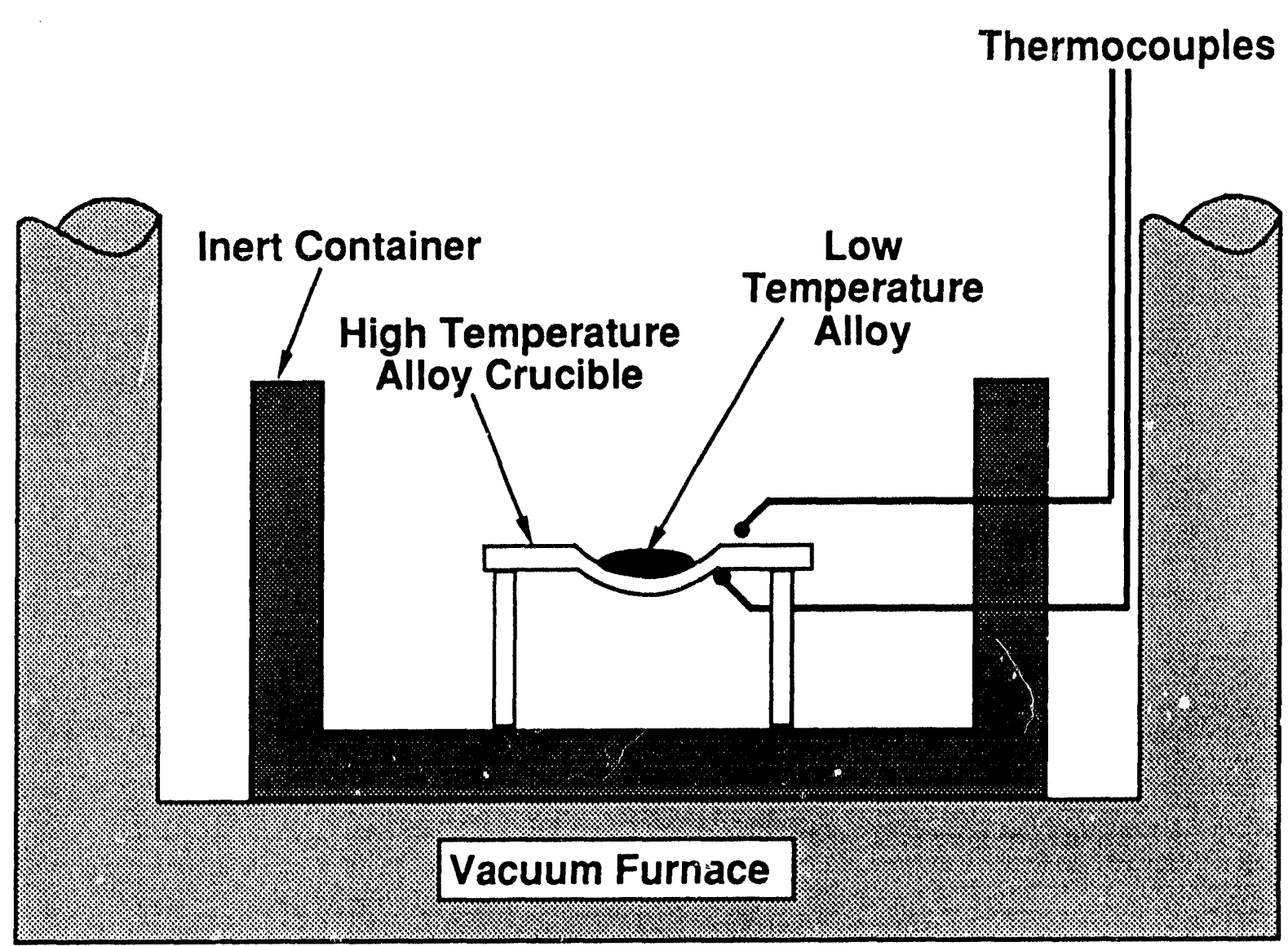

Figure 1. Schematic illustration of the general experimental arrangement for testing the compatibility of materials at high temperatures.

a)

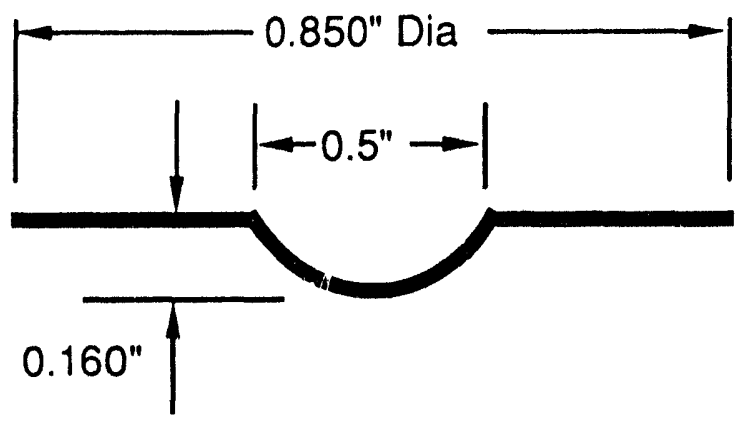

b)

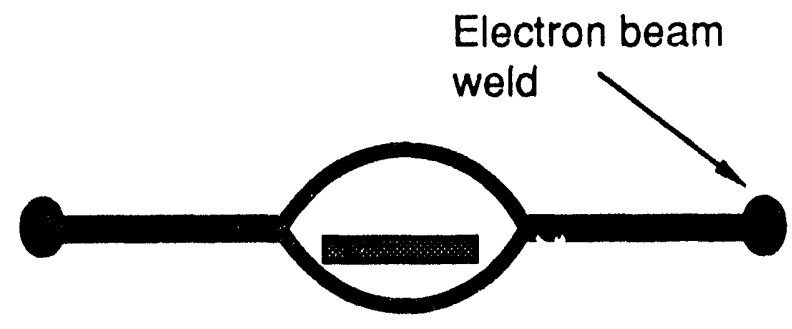

Figure 2. Geometry of the vanadium and 21-6-9 stainless steel crucibles for exposures (a) less than 2 hours at $1200^{\circ} \mathrm{C}$, and (b) $1200^{\circ} \mathrm{C}$ for 2 hours. 
a)

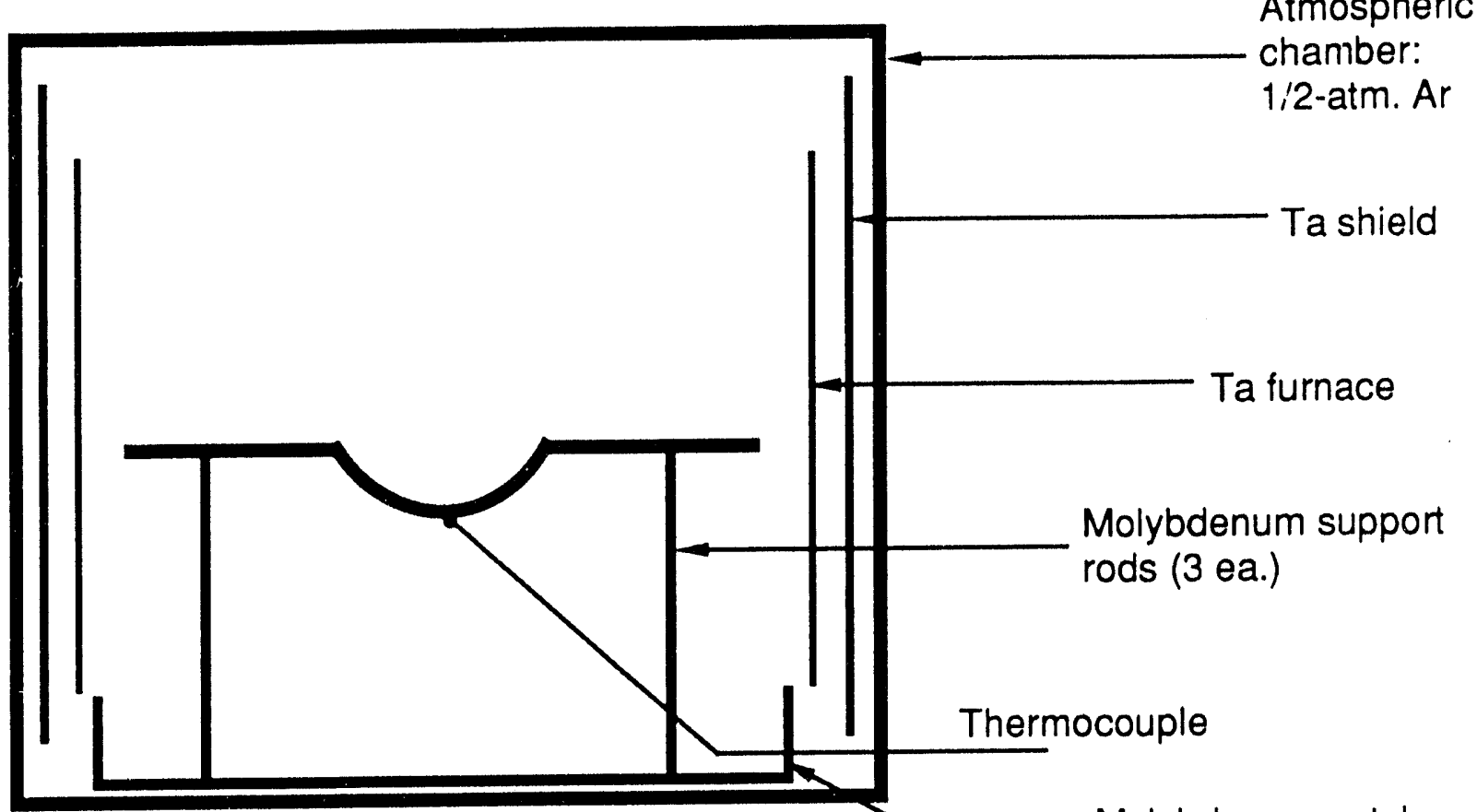

Molybdenum catch pan

b)

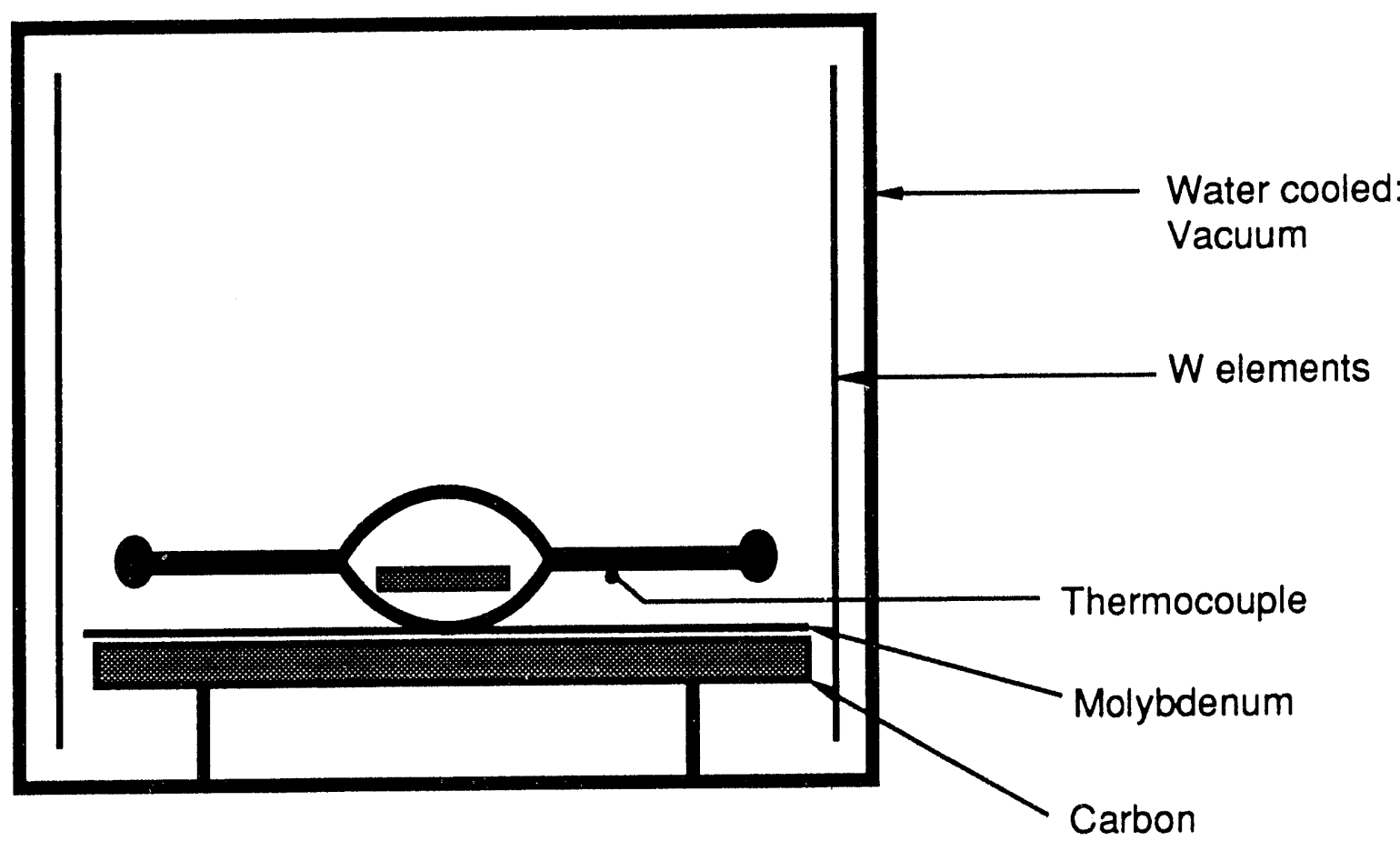

Figure 3. Furnace configurations for exposures of (a) less than 2 hours and (b) 2 hours. 
Temperature $\left({ }^{\circ} \mathrm{C}\right)$

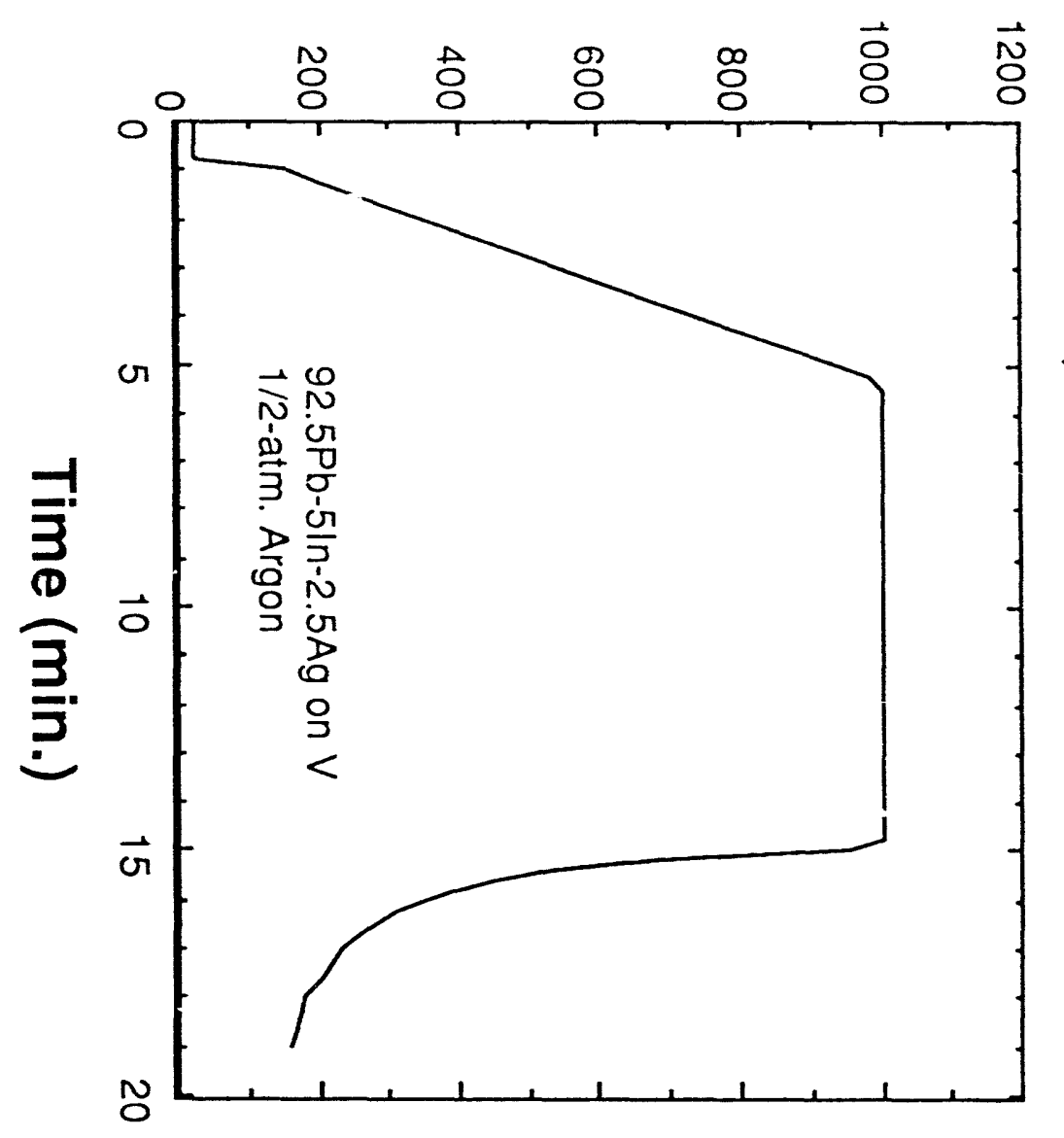




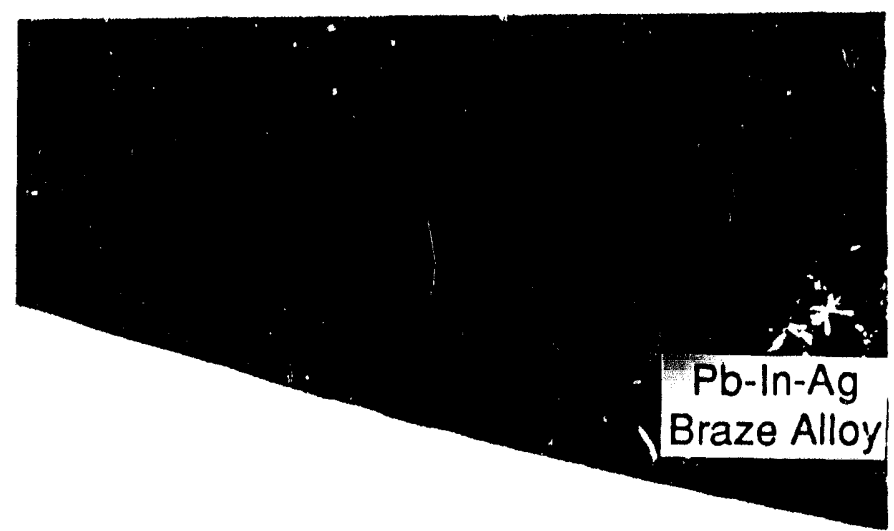

Vanadium

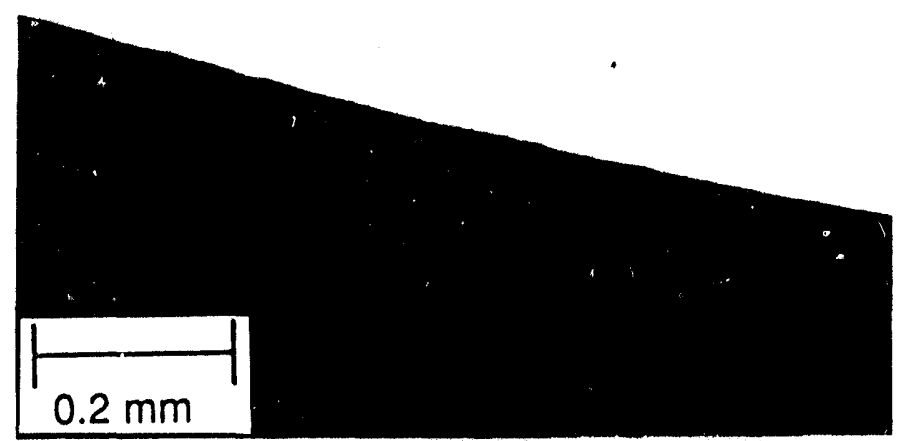

Figure 5(a). Micrograph showing the result of an $1100^{\circ} \mathrm{C} 60$-minute exposure of commercially pure vanadium to the $\mathrm{Pb}$-In- $\mathrm{Ag}$ braze alloy. (a) Low magnification view of a cross section of the crucible and solidified pool.



Figure 5(b). Micrograph showing the result of an $1100{ }^{\circ} \mathrm{C} 60$-minute exposure of commercially pure vanadium to the $\mathrm{Pb}$-In-Ag braze alloy. (b) High magnification view of the interface between the alloys. 


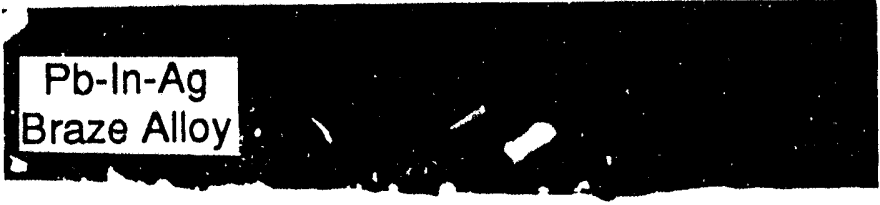

21-6-9

Stainless Steel

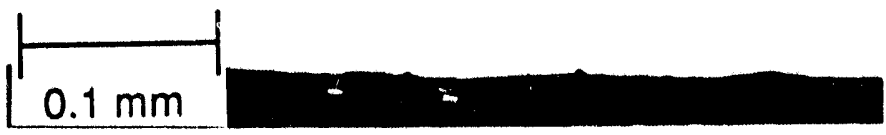

Figure 6(a). Micrograph showing the result of a $1200^{\circ} \mathrm{C}$ 2-hour exposure of 21-6-9 stainless steel to the $\mathrm{Pb}$-In-Ag braze alloy. (a) Low magnification view of a cross-section of the crucible and solidified pool.

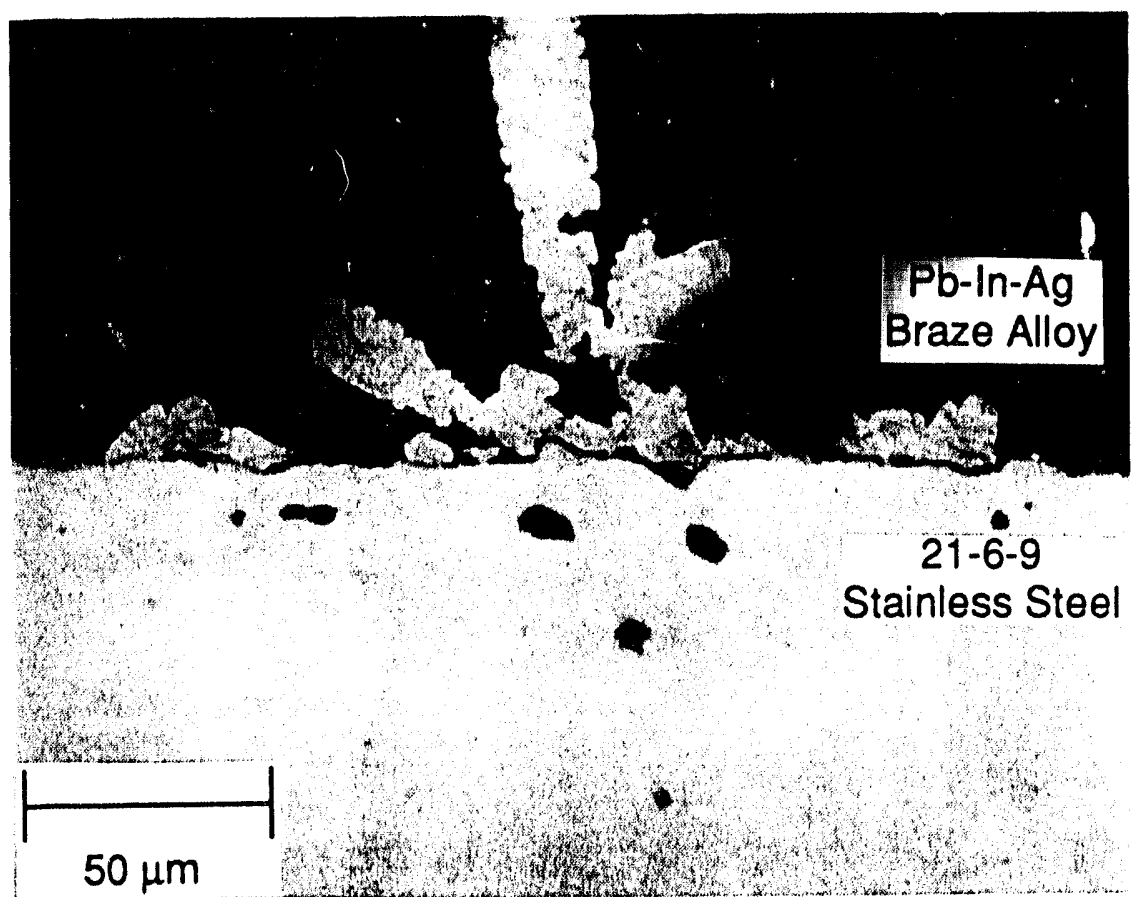

Figure 6(b). Micrograph showing the result of a $1200^{\circ} \mathrm{C}$ 2-hour exposure of 21-6-9 stainless steel to the Pb-In-Ag braze alloy. (b) High magnification view of the interface between the alloys. 

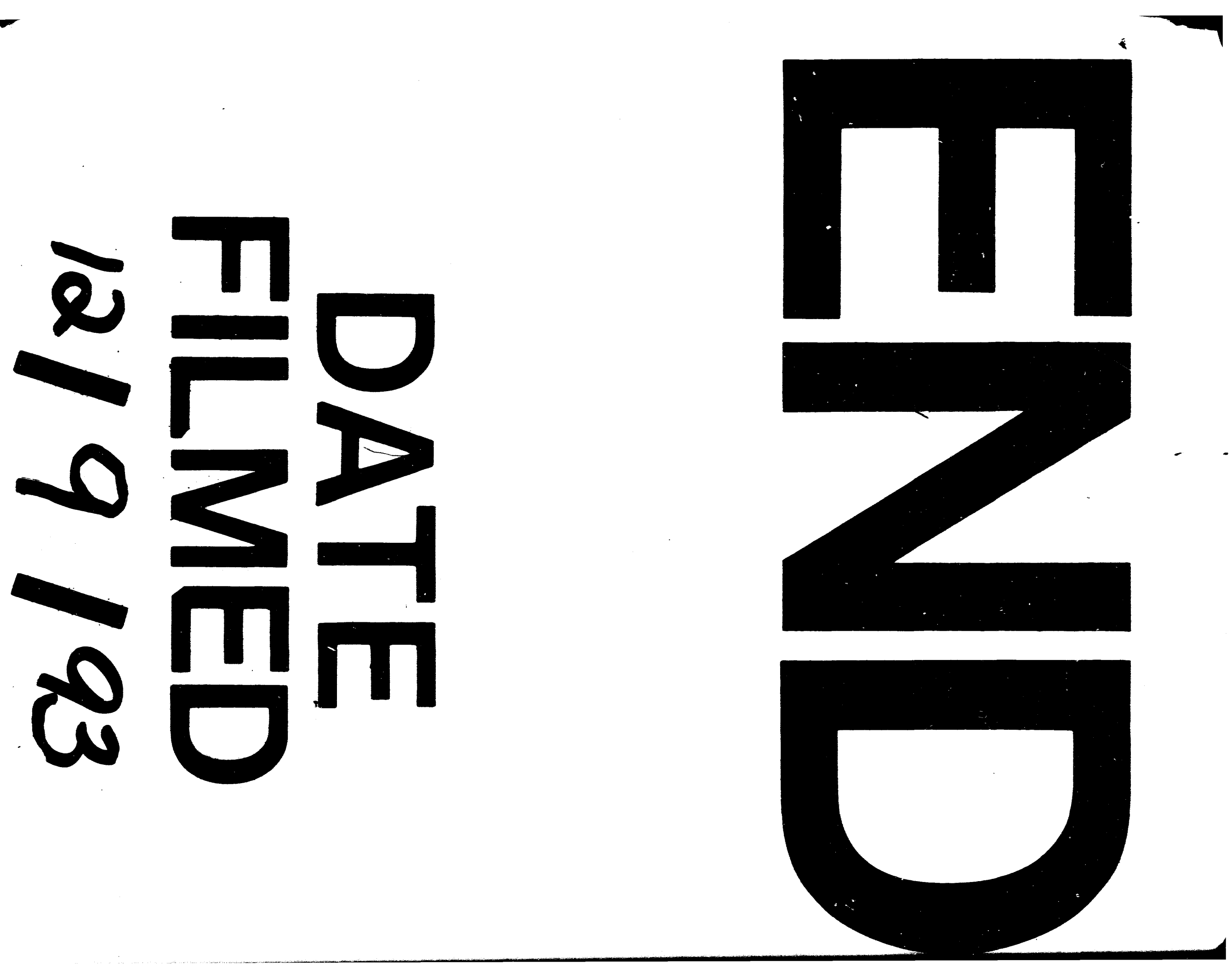
